Hispania Sacra, LXII

125, enero-junio 2010, 181-211, ISSN: 0018-215-X

\title{
MAGO CONTRA FALSARIO: UN DUELO DE INSULTOS ENTRE CALVINO Y SERVET**
}

\author{
MARÍA TAUSIET \\ Centro de Ciencias Humanas y Sociales, CSIC, Madrid
}

RESUMEN

El proceso contra el teólogo y médico español Miguel Servet, acusado por el consistorio de Ginebra de hereje y blasfemo en 1553, dio lugar a un largo y abstruso debate teológico entre dos posturas aparentemente irreconciliables. Con la intención de clarificar los términos de la discusión acerca de temas tan cruciales como la Trinidad e inmanencia divinas, o la inmortalidad del alma, Calvino y Servet acordaron mantener una discusión por escrito en latín que duró tres días (15-17 septiembre de 1553). En el contexto de un enfrentamiento que acabó convirtiéndose en un auténtico «duelo a muerte», si algo destaca por encima de cualquier argumentación es la utilización del insulto como arma retórica. Teniendo en cuenta que ambos contendientes estaban convencidos de defender la «verdadera fe», la mayoría de las descalificaciones expresaban la idea de falsedad del contrario. De este modo, según Servet, Calvino no era sino un impostor (un nuevo «Simon Magus»), mientras que éste tildó al español de calumniador $\mathrm{y}$ «falsario».

PALABRAS CLAVE: Insultos, Blasfemia, Impostura, Servet, Calvino.

\section{MAGUS VERSUS FALSARIUS: \\ A DUEL OF INSULTS BETWEEN CALVIN AND SERVETUS}

\section{ABSTRACT}

The trial of the Spanish theologian and physician Miguel Servet, charged with heresy and blasphemy by the Council of Geneva in 1553 , led to a long and

\footnotetext{
* Existe una versión inglesa reducida de este texto, en Reformation and Renaissance Review, 10.1 (2008), pp. 59-87.
} 
abstruse debate between two apparently irreconcilable standpoints. In an attempt to clarify the terms of discussion on such crucial areas as the Trinity, divine immanence and the immortality of the soul, Calvin and Servet embarked on a three-day written debate (15-17 September 1553$)$. In what ultimately became a genuine «duel to the death», what stands out, over and above the actual argumentation, is their use of insults as rhetorical weapons. Given that both adversaries were equally convinced that they were defending the «true faith», most of their attacks were aimed at demonstrating the false nature of their opponent. Thus, according to Servet, Calvin was nothing but an impostor (a latter-day «Simon Magus»), while Calvin branded the Spaniard a slanderer and «falsifier».

KEY WORDS: Insults, Blasphemy, Imposture, Servetus, Calvin.

Recibido/Received 07-09-2009

Aceptado/Accepted 09-12-2009

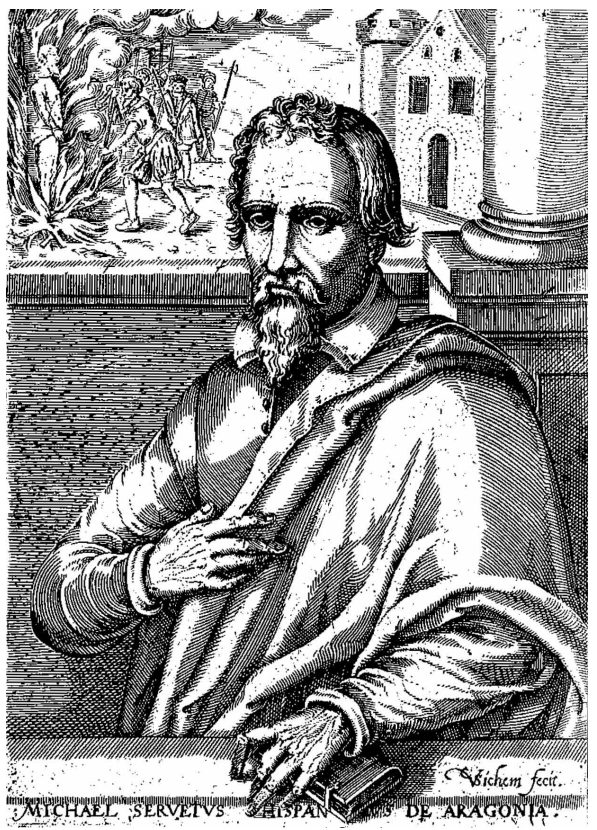

Miguel Servet (1511-1553). Grabado de Karel van Sichem, 1609.

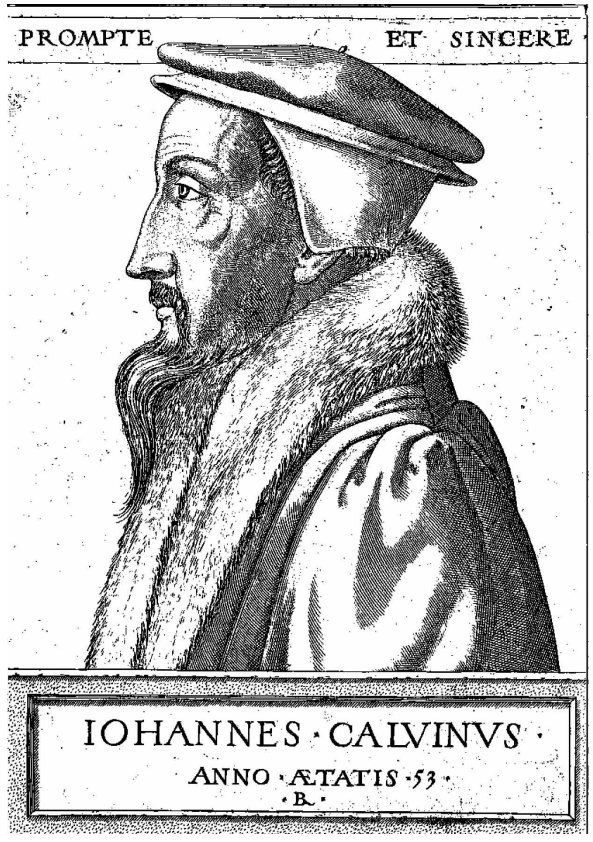

Jean Calvin (1509-1564). Grabado de René Boyvin, aprox. 1580 . 
«Con Simón el Mago, tú encierras a Dios en un rincón: yo digo que está presente en todas las cosas»

Miguel Servet ${ }^{1}$

«El falsario será atrapado»

Juan Calvino 2

En agosto de 1553, el médico y teólogo español Miguel Servet, que había llegado recientemente a Ginebra huyendo de sus enemigos, ${ }^{3}$ fue apresado por hereje y blasfemo o, dicho de otro modo, por propagar «falsa doctrina». ${ }^{4}$ En esta ocasión, sin embargo, no se trataba únicamente de condenar los errores de un hereje más, sino también de dirimir la afrenta personal del acusado con el jefe de la iglesia ginebrina, Juan Calvino, a quien Servet había difamado «con todas las injurias y blasfemias que se pueden inventar». ${ }^{5}$

Tras la denuncia formal que abrió el proceso contra el español, se sucedieron ocho largos interrogatorios destinados principalmente a examinar sus controvertidos puntos de vista referidos tanto a la divinidad -Trinidad e inmanencia- como al alma humana -inmortalidad. Estos provocaron un debate teológico entre Calvino y Servet difícil de desentrañar. ${ }^{6}$ Vista la falta de entendimiento entre dos posturas aparentemente irreconciliables, Servet solicitó el arbitraje del resto de las iglesias suizas. Calvino aceptó con la condición de que ambos continuaran la discusión por escrito y en latín. ${ }^{7}$ De ese modo, podrían

\footnotetext{
1 «Cum Simone Mago tu Deum in angulo recludis: ego eum dico esse omnia in omnibus» Vid. G. BAum, E. Cunitz y E. REuss et al. (eds.), Calvini opera quae supersunt omnia, 59 vols., Braunschweig, 1863-1900, vol. VIII, p. 548. Las traducciones al español de dicha obra están tomadas de Ángel ALCALÁ, Miguel Servet. Obras completas, Zaragoza, Prensas Universitarias de Zaragoza, 2003, vol. I, pp. 167-229.

2 «Falsarius deprehendetur» (Calv. op., VIII, p. 523).

${ }^{3}$ La fama de Ginebra como «ciudad de refugio» comenzó a extenderse a partir de 1550 , coincidiendo con la llegada de una primera oleada de reformadores religiosos, en su mayoría franceses e italianos, que habían abandonado sus países de origen para huir de sus perseguidores (vid. William MoNTER, Calvin's Geneva, Nueva York, John Wiley \& Sons, 1967, p. 82). No obstante, en el caso de Servet, dicha fama acabaría por culminar «en trágica y paradójica ironía» (Ángel AlCALÁ, Miguel Servet. Obras completas, vol. I, p. XV).

4 «Le seigneur lieutenant a presente les responses de ung nome Michel Servet charge de faulse doctrine», Extrait des Registres du Petit Conseil, 15-8-1553 (Calv. op., VIII, p. 736).

5 Según el artículo 39 de la demanda criminal, presentada por Nicolás de la Fontaine, a petición del mismo Calvino: «XXXIX. Item quen la personne de Msr. Calvyn, ministre de la parolle de Dieu en ceste Eglise de Geneve, il a difamé para livre imprimé la doctrine que s'i presche prononceant toutes les iniures et blasphemes qui est possible dinventer.» (Calv. op., VIII, pp. 730-731).

6 Vid. Daniel Moreno Moreno, «Servet y Calvino: un diálogo a muerte», en Sergio BACHES OPI (ed.), Estudios sobre Miguel Servet (II), Zaragoza, I.E.S. Miguel Servet, 2006, pp. 49-86.

${ }^{7}$ El 1 de septiembre de 1553, tras el octavo interrogatorio a Servet, el tribunal tomó la decisión de proporcionar al acusado los medios para continuar el debate por escrito con Calvino, dado lo mucho que estaba alargándose una discusión prácticamente indescifrable: «Mais pource que seroit trop long
} 
clarificarse los términos de la controversia y, al mismo tiempo, se contaría con un documento probatorio para enviar a las iglesias de Zurich, Berna, Basilea y Schaffhausen, por si llegaba la ocasión de que tuvieran que intervenir en el proceso, lo que en efecto sucedió poco tiempo después.

El debate por escrito entre Calvino y Servet duró tres días, ${ }^{8}$ en los que la intensidad de la discusión alcanzó cotas extraordinarias. Los recursos utilizados por los dos contendientes para derribar los argumentos del adversario excedieron los límites del razonamiento discursivo. Ambos utilizaron sistemáticamente la descalificación personal del contrario y, en particular, Servet cubrió a Calvino de una serie de insultos y desprecios que hoy nos sorprenden por su violencia y temeridad, sobre todo teniendo en cuenta la posición de debilidad en que se encontraba: privado de libertad en manos de sus acusadores.

El acalorado enfrentamiento verbal entre los dos teólogos ocultaba en el fondo un auténtico duelo a muerte, como acabó demostrándose cinco días después de finalizar el debate escrito, cuando el reo decidió enviar una súplica a sus jueces en la que incluía una denuncia a Calvino por haberle acusado falsamente, entre otras cosas de negar la inmortalidad del alma. Según Servet, en tanto que «falso acusador», Calvino debía ser juzgado y expuesto a la misma pena solicitada para él:

«De entre todas las herejías y crímenes, no hay uno más grande que el de considerar el alma mortal [...]. Quien afirma eso no cree que haya Dios, ni justicia, ni resurrección, ni Jesucristo, ni Santa Escritura, ni nada, sino que todo es muerte, y que el hombre y la bestia son todo uno. Si yo hubiera dicho eso [...] debería condenarme a muerte a mí mismo. Por tanto, os pido, honorables señores, que mi falso acusador sea castigado a la pena del talión y que sea detenido y preso como yo, hasta que la causa quede sustanciada definitivamente por mi muerte o la suya u otra pena. Y para hacer esto, yo me inscribo contra él a la dicha pena de talión. Y estaré contento de morir, aunque sea sin convencerle, tanto de esto como de otras cosas». ${ }^{9}$

douyr yey le discours et que se seroit chose trop confuse est este advise que audict Servet soit baille deu papier et de lencre et que en latin il mette par escript ses responces et preuves, et que puys apres Mr. Calvin responde aussi par escript en latin. Et puys apres est este encor advise que Mr. Calvin donra en latin par escript les articles de mot a mot qui son au livre dudict Servet, et puys il y respondra et prouvera par escript en latin iceux articles» (Calv. op., VIII, p. 793).

${ }^{8} \mathrm{La}$ discusión tuvo lugar entre los días 15 y 17 de septiembre. El texto de la misma aparece en las obras completas de Calvino, ya que éste lo publicó como parte integrante de su Defensio con el fin de justificar su conducta frente a Servet. Así, pues, la discusión aparece encabezada con el título: «Frases o proposiciones sacadas de los libros de Miguel Servet que los ministros de las iglesias de Ginebra estiman ser impías y blasfemas de Dios, unas; llenas de errores y delirios profanos, otras; y todas, totalmente ajenas a la palabra de Dios y al consenso ortodoxo de la Iglesia. Respuestas de Servet. Breve refutación de los errores e impiedades de Miguel Servet por los ministros de la Iglesia de Ginebra, como se les había mandado».

${ }^{9}$ El 22 de septiembre, Servet escribía: «En toutes les aultres heresies et en tous les aultres crimes, ne a poynt si grand que de faire lame mortelle [...] Qui dict cela ne croyt poynt quil y aye Dieu, ni jus-

Hispania Sacra, LXII

125, enero-junio 2010, 181-211, ISSN: 0018-215-X 
En realidad, el duelo verbal entre Calvino y Servet no se ciñó al ámbito de la palabra, sino que -utilizando una expresión acuñada por el antropólogo Marcel Mauss- acabó convirtiéndose en un «fenómeno social total», por la riqueza de su significado y por sus numerosas implicaciones..$^{10}$ En efecto, el «combate singular» que enfrentó a los dos afectados en el marco de una controversia teológica sobre los atributos de la divinidad y el alma, trascendió la materia de la discusión para convertirse en una tentativa contra-institucional -por parte de Servet-, en una defensa de la honra propia -por parte de Calvino-, en una manifestación política de apoyo y lealtad a Calvino -por parte del Consistorio ginebrino y del resto de las iglesias suizas- y, por encima de todo, en una expresión ritual de carácter profundamente religioso que para ambos contendientes suponía una lucha denodada contra los poderes del mal representados en la persona del contrario. ${ }^{11}$

\section{INSULTOS}

A lo largo del debate, Servet insistió principalmente en la falsedad de Calvino, a quien aplicó el sobrenombre de Simón el Mago, identificándolo de este modo con el hechicero bíblico prototipo del embaucador. Ensartando un insulto tras otro, Servet afirmó que Calvino era no sólo un astuto dialéctico y un peligroso sofista, tergiversador y pervertidor de cuanto llegaba a sus oídos, sino básicamente un desvergonzado hipócrita, mentiroso, pérfido y falaz. La noción epistemológica de falsedad, que acabaría constituyendo el meollo de las injurias de ambos contendientes, aparecía inevitablemente asociada con el concepto moral de maldad. Calvino fue asimismo calificado por su oponente de miserable, infame, perverso y maldito, además de rabioso y homicida. Desde el punto de vista de Servet, las aberraciones de Calvino sólo podían explicarse por su

\footnotetext{
tice, ni resurrection, ni Iesu Crhist, ni saincte escriture, ni rien: si non que tout e morrt, et que home et beste soyt tout un. Su iaves dict cela [...] ie me condemnares moy mesme a mort. Pour quoy, messeigneurs, ie demande que mon faulx accusateur soyt puni poena talionis: et que soyt detenu prisonier comme moy, iusques a ce que la cause soyt diffinie pour mort de luy ou de moy ou alutre poine. Et pour ce faire ie me inscris contra luy a la dicte poine de talion. Et suys content de morir, si non est convencu, tant de cecy, que daultres choses [...]» (Calv. op., VIII, p. 805).

${ }^{10}$ Vid. Marcel Mauss, «Essai sur le don. Forme et raison de l'échange dans les sociétés archaïques», en Sociologie at Anthropologie, París, Presses Universitaires de France, 1950 (1ª ed., 19231924), y Georges BALANDIER, «Phénomènes sociaux totaux et dynamique sociale», Cahiers internationaux de sociologie, vol. 30 (1961), pp. 23-34.

${ }^{11}$ Vid. François BillacoIs, Le duel dans la societé française des XVIe-XVIIe siècles. Essai de psychosociologie historique, París, Éditions de l'École des Hautes Études en Sciences Sociales, 1986, p. 12, Claude Chauchadis, «Duel sémantique au Siècle d'Or: Desafío \& Duelo», Les Cahiers de Fontenay, 46-48 (1987), pp. 69-81, y La loi du duel. Le code du point d'honneur dans l'Espagne des XVI ${ }^{-}$ XVII e siècles, Toulouse, Presses Universitaires du Mirail, 1997, pp. 11-36.
} 
profunda ignorancia, de ahí que además de llamarlo ciego y sordo, exclamara: « Nada entiendes!. ${ }^{12}$ [...]. Tal es tu desvergüenza: condenas cuanto ignoras. ¡Lo único que sabes es gramática!». ${ }^{13}$ La naturaleza ilusoria que Servet atribuía a la doctrina de Calvino quedaba corroborada al tachar a éste de fantasma y rechazar sus propuestas como vanas quimeras. Por si lo anterior no fuera suficiente, Servet insultó a Calvino con todo tipo de calificativos denigrantes, desde los meramente despectivos, como perro o ridículo ratón, hasta los más irreverentes, llegando al extremo de tildarlo de archidemonio.

Como contrapartida, Calvino, menos directo y ofensivo, pero no por ello menos contundente, no se quedó atrás en sus descalificaciones. Para él, Servet era fundamentalmente un falsario y un insolente calumniador; no contento con su orgullo, su arrogancia y su extrema vanidad, el canalla presumido no dejaba de vomitar errores y sacrilegios por su boca, lo que lo convertía en un impío y detestable blasfemo. Del mismo modo que Servet insistía en la ignorancia de Calvino, éste incidía una y otra vez en la ciega obstinación del español, en su frivolidad y, por encima de todo, en lo que calificaba de extraña locura rabiosa, ya que sus delirios y desvaríos le llevaban a defender todo tipo de monstruosidades. Desde su punto de vista, las prevaricaciones y desatinos de Servet, producto de una evidente carencia de sentido común, lo convertían no sólo en un corrupto libertino, sino, peor aún, en un peligroso hereje al que llegó a calificar de maniqueo y pelagiano.

Antes de examinar la naturaleza de las injurias específicas lanzadas por ambos contendientes, conviene tener presente el carácter fundamentalmente ritual de los insultos durante la Edad Moderna. Utilizados a menudo como un arma retórica, representaban una estrategia más dentro de la oratoria dirigida a convencer o a disuadir. Como ha señalado Peter Burke, «aunque, en cierto modo, los insultos suponían una infracción de las normas (lo que llevaba a la intervención de los tribunales); por otro lado, observaban determinadas reglas y convenciones casi tan estrictamente como un soneto. Estaban estereotipados, o [...] ritualizados. No obstante, como en el caso del soneto, las reglas dejaban un margen considerable para la creatividad y la invención». ${ }^{14}$ Según Burke, los insultos, («actos de comunicación» dirigidos contra un individuo, grupo o institución), nos dicen mucho acerca de la cultura en que fueron empleados, sobre

\footnotetext{
12 «Tibi non intelligenti» (Calv. op., VIII, p. 521).

13 «Haec est impudentia tua iudicare quae nescias. Vere, sed solam grammaticam» (Calv. op., VIII, p. 545).

14 «These acts, a breach of the rules in one sense (leading to the intervention of the Tribunal), in another sense followed rules or conventions almost as closely as the sonnet. They were stereotyped, or [...] 'ritualised'. As in the case of the sonnet, however, these rules allowed considerable scope for creativity and invention». Vid. Peter Burke, «The Art of Insult in Early Modern Italy», Culture and History, vol. 2 (1987), p. 69.
} 
todo si tenemos en cuenta la enorme riqueza del «vocabulario del vilipendio», así como las sutiles distinciones de significado entre calificativos aparentemente similares. ${ }^{15}$

La omnipresencia de los insultos a lo largo de la Edad Moderna se relaciona estrechamente con la creencia arraigada en el poder extraordinario de las palabras. Consideradas capaces de conectar el deseo (pensamiento) con la realidad, las palabras en general eran respetadas, veneradas y temidas en todos los ámbitos. ${ }^{16}$ Por lo que respecta a los insultos, la convicción de que determinados improperios poseían la virtud de ahuyentar el mal se observa ya desde la Antigüedad en determinados ritos religiosos, como los celebrados en honor a Deméter en Eleusis para favorecer la fertilidad de los campos. ${ }^{17}$ Dentro del contexto de la magia simpática, la creencia tradicional en el poder de las palabras como transmisoras del llamado pensamiento ilusorio (wishful thinking) ${ }^{18}$ era especialmente patente, como se demuestra en muchos conjuros o encantamientos cargados de una enorme violencia verbal. ${ }^{19}$

Los insultos y las imprecaciones formaban parte asimismo del vocabulario oficial utilizado por la Iglesia para condenar a quienes se apartaban del camino recto, como expresión de la ira divina. De ahí que determinadas maldiciones dirigidas contra los pecadores aparecieran en los anatemas y sentencias de excomunión con un supuesto valor profético o pastoral ya que, en teoría, su objetivo no era la destrucción del pecador, sino la corrección del pecado. En ese sentido, al decir de los teólogos, no debían traducirse como una manifestación de venganza personal, sino como un instrumento de la cólera divina. ${ }^{20}$

15 «Insults thus offer us a key to the history of mentalities or value-systems». Vid Peter BURKE, op. cit., p. 70 .

16 Vid. Peter Burke y Roy Porter (eds.), The Social History of Language, Cambridge, Cambridge University Press, 1987.

${ }^{17}$ En los misterios eleusinos (ritos en honor a las diosas agrícolas Deméter y Perséfone, que se celebraban en la antigua Grecia al llegar la primavera) tenía lugar una procesión que partía desde Atenas y tenía como destino la localidad de Eleusis, situada a treinta kilómetros de distancia. En el transcurso del llamado «camino sagrado» tenían lugar varios actos litúrgicos. En uno de ellos, al atravesar un puente sobre el río Kefisio, «unos hombres disfrazados con máscaras lanzaban insultos contra los ciudadanos más importantes». Vid. Mircea Eliade, Historia de las creencias y de las ideas religiosas, vol. I, Barcelona, Paidós, 1999, p. 379.

18 Dicho término tiene sus orígenes en la psicología freudiana. Vid., especialmente, el capítulo «Animismo, magia y la omnipotencia del pensamiento», en Sigmund FrEUD, Tótem y tabú [1 $1^{\mathrm{a}}$ ed., 1912], Madrid, Alianza, 1999.

19 Vid. María TAUSIET, Abracadabra Omnipotens. Magia urbana en Zaragoza en la Edad Moderna, Madrid, Siglo XXI, pp. 79-132.

${ }^{20}$ Resulta interesante la distinción entre los cuatro términos utilizados por la Iglesia desde la Edad Media en sus cláusulas conminatorias: Maledictus (que posee un sentido general), Damnatus (que designa al merecedor del castigo supremo, esto es, de la exclusión de la vida eterna), Excommunicatus 
La interpretación de la naturaleza sagrada de las maldiciones variaba por completo, si quien las profería no era la Iglesia sino el pecador. De ahí el concepto de blasfemia, que en esta época se utilizaba con, al menos, dos sentidos diferentes: uno general (ya que cualquier palabra injuriosa era considerada blasfema), y otro estricto (entendiendo por blasfemiasl as palabras sacrílegas pronunciadas contra Dios y, por extensión, contra todo lo relativo a la religión).

Pero, como se ha señalado a menudo, quienes proferían las mayores blasfemias y juramentos no eran los tibios o descreídos, sino, paradójicamente, quienes experimentaban una vivencia religiosa más personal y profunda. Expresaban así sus conflictos interiores y, de algún modo, su búsqueda sincera de la verdad. ${ }^{21}$ Si bien se trataba de una verdad que no coincidía con la «verdad religiosa» en un sentido dogmático, al menos sí expresaba un tipo de «verdad emocional» dirigida al reconocimiento de los sentimientos más genuinos. Como afirma Mauren Flynn: «Los filósofos escolásticos de la Edad Media y de la Edad Moderna creían que todo lenguaje, y en especial las expresiones más espontáneas, ponía al descubierto nuestra relación íntima con el orden sagrado de las cosas, revelando el verdadero sentimiento de nuestras almas».22

La búsqueda activa de la verdad religiosa personal mediante la expresión espontánea de las emociones se materializaba a menudo en juramentos airados contra Dios y contra todo lo sagrado, como una forma más del lenguaje cotidiano en una gran parte de la población. No hay que olvidar que, en sus sermones y escritos, también los teólogos cometían constantes transgresiones lingüísticas, en especial, insultos proferidos contra sus oponentes religiosos, que se deslizaban entre los argumentos más alambicados. Desde Erasmo de Rotterdam hasta John Milton, desde Lutero hasta el propio Calvino, los testimonios que

(que implica una revancha puramente eclesiástica, en tanto que el excomulgado es excluido de la comunidad de los fieles) y Anathematizatus (que reúne los ámbitos de lo eclesiástico y lo escatológico, pues se considera «anatema» al pecador cuya falta es tan grave que su sentencia de excomunión se acompaña de una maldición anticipando su destino futuro). Vid. Michel ZIMMERMANN, «Le vocabulaire latin de la malédiction du IX ${ }^{\mathrm{e}}$ au XIII siècle. Construction d'un discours eschatologique», en Atalaya. Revue Française d'Études Médiévales Hispaniques (Actas del coloquio L'invective au Moyen Age. France, Espagne, Italie, organizado por E. Beaumatin y M. Garcia), vol. 5 (1994), pp. 37-55, y María TAUSIET, «Excluded Souls: The Wayward and Excommunicated in Counter-Reformation Spain», History, vol. 88 (2003), $\mathrm{n}^{\circ} 291$, pp. 437-450.

21 Vid. Geoffrey Hughes, Swearing: A Social History of Foul Language, Oaths and Profanity in English, Oxford, Blackwell, 1991.

22 «Scholastic philosophers of the medieval and early modern periods believed that all language, and particularly spontaneous utterances, exposed our intimate relationship to the sacred order of things, revealing the true sentiment of our souls». Vid. Maureen FlYNN, «Blasphemy and the Play of Anger in Sixteenth-Century Spain», Past and Present, vol. 149 (1995), p. 34.

Hispania Sacra, LXII

125, enero-junio 2010, 181-211, ISSN: 0018-215-X 
nos han llegado de los humanistas y de los reformadores de este período aparecen plagados de escarnios e improperios. ${ }^{23}$

Insultar al adversario religioso suponía no tanto un desprecio y una ofensa personales como una forma retórica de introducir el humor, la comicidad y la parodia: un punto de vista que complementaba la severidad intelectual de las discusiones. La mayoría de los insultos provocaban una risa burlona y un rechazo mucho más inmediatos que los más refinados argumentos destinados a refutar seriamente lo que querían condenar. En realidad, ambos tonos convivían sin conflicto alguno. Según John K. Hate, esta faceta irreverente y apenas estudiada de ciertos humanistas cristianos, como el poeta John Milton, constituía una elección deliberada: «Llamo la atención de estas joyas del vituperio, porque nos muestran un lado de Milton que tendemos a ignorar. En sus insultos, tanto humorísticos como ofensivos, está haciendo elecciones estilísticas deliberadas y revelando su carácter como tratadista de retórica. Aplicando los recursos de sus lecturas y de su vívida imaginación a las oportunidades de insultar, se muestra hairetikos en sentido estricto, pues el término griego original significa 'capaz de elegir'». ${ }^{24}$

En ese sentido, insultar no suponía únicamente una forma de guerra verbal 25 o una liberación individual de tipo psicológico (un alivio catártico de «la carga peligrosa que pesa en el corazón»), ${ }^{26}$ sino una elección -hairesis-, y, en ocasiones, incluso una táctica, esto es, una manera calculada de conducirse para el logro de un fin determinado. Tal es el caso de Lutero, cuyo «talento para la invectiva», de sobras conocido, le llevó con frecuencia «a arremeter contra sus enemigos, llamándolos necios, locos o endemoniados y calificando sus ideas de demenciales, insensatas, enloquecidas, ilusorias, imbéciles, delirantes, furiosas o inspiradas por el diablo». ${ }^{27}$

\footnotetext{
${ }^{23}$ Vid. John K. HALE, «Milton and the rationale of insulting», en Stephen B. DORRANSKI y John P. Rumrich (eds.), Milton and Heresy, Cambridge, Cambridge University Press, 1998, pp. 160-164.

24 «I call attention to his gems of vituperation, because they show us a side of Milton that we tend to ignore. In his insults, their humor and their offensiveness alike, he is making deliberate stylistic choices and revealing his character as a rhetor. Applying to his occasions of insulting the resources of his reading and his vivid imagination, he shows himself hairetikos in the primary sense: the Greek word first meant 'able to choose'». Vid. John K. HaLE, op. cit., p. 159.

${ }^{25}$ Los insultos y palabras blasfemas se utilizaban a menudo como una forma de establecer la superioridad en una discusión, así como de intensificarla, ya que fácilmente conseguían provocar la ira del contrario. En realidad, la mayoría de las discusiones estaban bastante ritualizadas, pues el recurso a la blasfemia suponía una manera eficaz de hundir el honor del oponente. Vid. Francisca LoETz, «How to Do Things With God: Blasphemy in Early Modern Switzerland», en Mary LindeMANN (ed.), Ways of Knowing; Ten Interdisciplinary Essays, Boston y Leiden, Brill, 2004, pp. 137-151.

26 «That perilous staff that weighs about the heart». Vid. Robert C. ElLIot, The Power of Satire: Magic, Ritual, Art, Princeton, Princeton University Press, 1960.

27 «Luther often blasted his enemies as fools, madmen and demoniacs, and their ideas as demented, insane, crazy, deluded, imbecile, delirious, furious, demonically inspired». Vid. H. C. Erik MiDELFORT, A History of Madness in Sixteenth-Century Germany, Stanford, Stanford University Press, 1999, p. 83.
} 


\section{BLASFEMIAS}

A los ojos de Calvino, Servet no era un simple hereje sino, por encima de todo, un consumado blasfemo. Desde su punto de vista, tal calificativo resultaba doblemente apropiado por los ataques del español contra su persona y contra su doctrina y, en consecuencia, contra la misma divinidad. Convencido de hallarse en posesión de la verdad, Calvino juzgaba cada uno de los reparos y objeciones de Servet a su credo graves ofensas contra el Altísimo, que, por tanto, no podían quedar sin castigo. Como ha señalado Philip Benedict, uno de los rasgos de Calvino que más llaman la atención es «la impresionante seguridad de que sus opiniones representaban la pura palabra de Dios»y, al mismo tiempo, «un miedo aparente a que la menor concesión pudiera abrir la puerta a un desenfrenado desorden». ${ }^{28}$

La obsesión de Calvino por discernir lo verdadero de lo falso y el exceso de celo por purgar o depurar todos los aspectos de la vida religiosa se muestran con claridad en su airada actitud hacia la doctrina de la transubstanciación. Influido por la principal obra de Zwinglio, cuyo expresivo título rezaba De la verdadera y la falsa religión (1525), ${ }^{29}$ aunque Calvino no compartía con el reformador suizo la lectura puramente simbólica de la Eucaristía, sí coincidía con él en su absoluta repulsa de los rituales católicos, a los que llegó a calificar de «verdaderas invenciones del diablo», «espantosas abominaciones», además de «la mayor infamia e insufrible blasfemia del negocio papal». ${ }^{30}$ Tal era su aversión a lo que él consideraba idolatría y «falso culto» que, en una de sus imágenes escatológicas más impactantes, no vaciló en comparar a quienes continuaban practicando los ritos católicos con limpiadores de letrinas que, dado su trabajo, han llegado a acostumbrarse de tal modo al hedor que no pueden entender por qué otros se tapan las narices en su presencia, pues, «endurecidos por el hábito, se sientan en sus propios excrementos, y aun así creen estar rodeados de rosas». ${ }^{31}$

Según Calvino, Cristo se hacía verdaderamente presente en el rito eucarístico, pero no de forma real o sustancial, ni tampoco meramente simbólica, sino puramente espiritual. Sea como fuere, lo importante para él era subrayar que la

28 «He combined [...] an awesome confidence that the views he defended represented the pure word of God, but also an apparent fear that the least concession might open the door to rampant disorder». Vid. Philip Benedict, Christ's Churches Purely Reformed. A Social History of Calvinism, New Haven y Londres, Yale University Press, 2002, p. 94.

29 Vid. Samuel M. JACKSON \& Clarence N. HelleR (eds.), Ulrich Zwingli, Commentary on True and False Religion, Durham, Labyrinth Press, 1929 y 1981.

30 «Veritable inventions of the Devil», «frightful abominations», «most wicked infamy and unbearable blasphemy forged in the shop of the papacy». Vid. Philp BENEDICT, op. cit., p. 85.

31 «Hardened by habit, they sin in their own excrement, and yet believe they are surrounded by roses». Ibidem, p. 86.

Hispania Sacra, LXII

125, enero-junio 2010, 181-211, ISSN: 0018-215-X 
Eucaristía constituía un alimento inmaterial para los creyentes, de modo que quienes no tuvieran la fe suficiente debían ser expulsados de la ceremonia, pues lo que para unos suponía un sustento, para otros era mortífero veneno. ${ }^{32}$ Este énfasis en mantener a la comunidad eucarística libre de toda polución es una pequeña muestra de la disciplina que el régimen calvinista llegó a imponer en todos los órdenes de la vida cotidiana. Desde las peleas domésticas, la ebriedad, el juego, la glotonería, la pereza o la llamada «ignorancia de la doctrina», hasta ciertas actitudes rebeldes de los jóvenes respecto a los mayores, o los bailes y canciones «profanos», un buen número de conductas, consideradas impías, quedaron prohibidas y fueron objeto de constantes multas y castigos. Entre estas conductas, se incluía, por supuesto, la costumbre de jurar y blasfemar, contemplada como uno de los peores sacrilegios. ${ }^{33}$

Ya desde antiguo, la blasfemia había sido considerada un delito mixto que ofendía a Dios y a los hombres y que, por ello, podía ser juzgado tanto por el poder eclesiástico como por el seglar. En la Ginebra teocrática de Calvino el fuero mixto aplicado a la blasfemia encontró su plasmación más rotunda, teniendo en cuenta la fusión de las esferas laica y religiosa. Para Calvino, la blasfemia constituía un crimen especialmente trascendente ya que «negar, desafiar o denunciar a Dios» activamente, por medio de la palabra, implicaba una forma de deshonrarle deliberada y atroz. ${ }^{34}$ De acuerdo con la cosmovisión de Calvino, Dios era infinitamente grande, sabio y todopoderoso. Frente a Él, el hombre (no sólo pequeño e ignorante sino, sobre todo, miserable y pecador), en su insignificancia, en este mundo solo tenía que servirle y glorificarle. Nada podía ser más grave, en consecuencia, que blasfemar contra El.

Tal afirmación, hasta cierto punto extensiva al mundo católico, se aplicó de manera mucho más estricta en el ámbito protestante. No hay que olvidar que la Reforma supuso una alteración fundamental de las formas de acercamiento de los fieles a lo sagrado, y que una de sus principales manifestaciones fue el énfasis puesto en la palabra -y su interpretación- frente al culto de las imágenes religiosas u otras formas de entrar en contacto con la divinidad, más dependientes de los sentidos que del puro intelecto. Las liturgias reformadas, en especial la calvinista, hicieron mucho hincapié en el control de la palabra bíblica, pero también de cualquier otra palabra que tuviera que ver con lo sagrado. Tanto es así que el hecho de blasfemar fue asociándose cada vez más con la sublevación, esto es, con la idea de la sedición, no tanto en un sentido religioso como pura-

\footnotetext{
32 Ibidem, p. 86.

33 Vid. E. William MonTER, «The Consistory of Geneva, 1559-1569», Bibliothèque d'Humanisme et Renaissance, vol. 38 (1976), p. 479.

34 Vid. David NAsh, Blasphemy in the Christian World. A History, Oxford, Oxford University Press, 2007, p. 50 .
} 
mente político. En palabras de David Nash, «con la llegada de la Reforma, la blasfemia llegó a equipararse a las creencias heréticas peligrosas para el sistema de gobierno. De ahí que la acusación empezara a utilizarse no sólo contra quienes se descuidaban, se emborrachaban o simplemente enturbiaban el orden público, sino también contra ciertos pensadores independientes». ${ }^{35}$

Para Calvino, el principal papel del Estado era proteger la verdadera religión, y el castigo y la venganza contra quienes osaban atacarla emanaban del mismo Dios. ${ }^{36}$ Según el historiador Roland H. Bainton, «para perseguir, un hombre debe creer que está en lo cierto, que el asunto en cuestión es importante y que la coerción será efectiva». ${ }^{37}$ Los tres requisitos se cumplieron con creces en el enfrentamiento entre Servet y Calvino. El líder de la iglesia ginebrina no era el único que confiaba absolutamente en la certeza de su fe sino que, a diferencia de Servet, contaba con numerosos partidarios que veían en él a un profundo devoto, así como al defensor de un ideal de suprema importancia para el destino de la humanidad. Desde el punto de vista de Calvino y sus seguidores, suprimir la disensión era como amputar un miembro enfermo para salvar una vida, en este caso la vida o la salud espiritual de la comunidad ginebrina que debía servir de ejemplo al resto de la cristiandad.

No hay que olvidar que, según la interpretación cristiana tradicional, el alma de los condenados por herejía quedaba purificada en el momento mismo de su muerte, pudiendo de este modo salvarse y alcanzar la vida eterna. No obstante, esa interpretación chocaba con uno de los principios fundamentales de la Reforma iniciada por Lutero, según el cual la salvación sólo dependía de la fe, la cual nunca podía forzarse por ser un don de Dios. ${ }^{38}$ En el caso de Calvino, teniendo en cuenta su defensa de la predestinación incondicional, esto es, de la decisión divina intemporal acerca de quiénes se salvarán y quiénes se condenarán sin tener en cuenta la conducta humana, la finalidad de la persecución religiosa tenía mucho más que ver con lo que se entendía por blasfemia que con cualquier tipo de compasión hacia los perseguidos, pues las condenas por herejía buscaban no tanto la redención final del pecador como «vengar el honor de Dios, silenciando a los que profanan su santo nombre». .39

\footnotetext{
35 «With the coming of Reformation blasphemy became equated with heretical beliefs dangerous to the polity. Henceforth the accusation began to be used against independent thinkers as well as the careless or drunks and miscreants who posed merely a nuisance». Ibidem, p. 4.

36 Vid. David NASH, op. cit., p. 52, y Diarmaid MaCculloch, Reformation: Europe's House Divided 1490-1700, Londres, Penguin, 2003, p. 188.

37 «To persecute, a man must believe that he is right, that the point in question is important, and that coercion is effective». Vid. Roland H. Bainton, The Reformation of the Sixteenth Century, Boston, The Beacon Press, 1952, p. 214.

38 Vid. Roland H. Bainton, The Reformation of the Sixteenth Century..., p. 225.

39 «The purpose was to vindicate the honor of God by silencing those who sully His holy name». Vid. Roland H. Bainton, Hunted Heretic. The Life and Death of Michael Servetus, Boston, The Bea- 
Al margen de consideraciones teóricas, resulta de todo punto imposible conocer el motivo último que llevó a Calvino a la determinación final de condenar a Servet a la pena de muerte. Decidir hasta qué punto pesaron más los factores personales o los puramente espirituales y valorar en qué proporción actuaron ambos sería, por nuestra parte, una tarea inasequible y vana. Si la conciencia de los vivos es ya difícil de penetrar, la de los muertos resulta todavía más inaccesible. Pese a todo, la violencia verbal que tuvo lugar entre los dos teólogos, así como la extrema violencia con que se ejecutó la sentencia de Servet-quemado a fuego lento con crueldad deliberada durante más de media hora, sin que le fuera concedida su petición de ser degollado para no desesperarse en el último momento-, nos obliga a reflexionar sobre los móviles del enfrentamiento entre ambos contendientes.

En el caso de Servet, dejando aparte su intrínseca temeridad (manifiesta desde el principio en su voluntaria decisión de acudir a Ginebra), la exagerada violencia verbal y la rabia demostradas contra Calvino podrían justificarse hasta cierto punto por la pésima situación en que llegó a encontrarse tras un mes en la cárcel, desprovisto de las condiciones más elementales de higiene y sin contar siquiera con el asesoramiento de un abogado. El 15 de septiembre de 1553, el mismo día en que comenzaría su debate escrito con Calvino, el reo se dirigía a sus jueces en estos términos:

«Os suplico muy humildemente que os plazca abreviar estas grandes dilaciones, o que me coloquéis fuera de la criminalidad. Veis que Calvino [...] quiere hacer que me pudra aquí en la cárcel. Los piojos me comen vivo, llevo los calzones rotos, y no tengo muda ni jubón, ni más camisa que la que llevo hecha jirones [...]. Os he pedido también un procurador o abogado, como habéis permitido a la otra parte, que no tenía de él tanta necesidad como yo que soy extranjero e ignorante de las costumbres de este país». ${ }^{40}$

Como señala Michèle Guillemont, en esta época el lenguaje blasfemo era característico de ciertos grupos de población, entre los que cabe destacar a los jugadores y, sobre todo, a los pobres que poblaban las cárceles. ${ }^{41}$ Hasta tal pun-

con Press, 1960, p. 170 (trad. esp., de Ángel AlCALÁ, Servet, el hereje perseguido, Madrid, Taurus, 1973, p. 177).

40 «Ie vous supplie tres humblement que vous plaise abreger ces grandes dilations ou me mette hors de la criminalité. Vous voyez que Calvin [...] me veut icy faire pourrir en la prison. Les poulx me mangent tout vif, mes chauses sont descirées et nay de quoy changer, ni perpoint, ni chamise que una mechante [...] Ie vous aussi demandé un procureur ou advocat, comme avies permis a ma partie, la quiele nen avoyt si a faire que moy que suys estrangier ignorant les costumes de ce pays.» (Calv. op., VIII, p. 797. Vid. también Ángel AlCaLÁ, Miguel Servet. Obras completas, vol. I, pp. 165-167).

${ }^{41}$ Vid. Michèle GuILLEMONT, Recherches sur la violence verbale en Espagne au XVIe et XVII e siècles (aspects sociaux, culturels et littéraires). Tesis doctoral inédita dirigida por Augustin Redondo y presentada en la Universidad de París III en diciembre de 2000, vol. I, pp. 84-87. 
to los juramentos y blasfemias distinguían el lenguaje de estos últimos (la «palabra de los prisioneros») $)^{42}$ que un tratado español del siglo XVI sobre el cuidado con que debía tratarse a los presos incluía un capítulo titulado: «Que los juezes deven tener cuydado que a los presos no se les haga mal tratamiento en las cárceles, y que no ofendan a Dios». ${ }^{43}$ Pese a que la mansedumbre y el respeto a la autoridad se considerasen virtudes cristianas, resulta interesante que la cólera, vista como una locura momentánea, pudiera ser alegada como circunstancia atenuante a la hora de juzgar a los blasfemos, a quienes, habiendo perdido el control de su voluntad, se consideraba que quedaban reducidos a un estado casi animal. 44

En el otro extremo, la posición de superioridad objetiva de Calvino era indudable. No obstante, los ataques de Servet podían suponer un importante peligro para su honor. Nunca había sido tratado con tanta ferocidad, al menos en público. Entre los motivos por los que convenía encerrar y, llegado el caso, eliminar a la bestia que se le oponía, estaban sin duda la defensa de su fama tan fieramente puesta en entredicho. ${ }^{45}$ De hecho, tal y como consta en la petición criminal del proceso, el español había sido preso por cuatro motivos principales: dos espirituales (las blasfemias que ha pronunciado y escrito contra Dios», y «las herejías con que ha infestado el mundo»), y otros dos terrenales («las malvadas calumnias y falsas difamaciones que ha sembrado contra los verdaderos servidores de Dios, y en particular contra el señor Calvino, cuyo honor el demandante está obligado a defender», y «la vergüenza y el deshonor que podrían caer sobre la iglesia de Ginebra»). 46

Las páginas que siguen desglosan algunas de las «calumnias» $\mathrm{y}$ «difamaciones» que Servet y Calvino intercambiaron durante los tres días que duró su debate escrito, sin olvidar el marco teológico que las proveía de sentido.

42 Ibidem, p. 86.

43 Véase Bernardino de SANDoval, Tractado del cuydado que se debe tener de los presos pobres, en que se trata ser obra pía proveer a las necessidades que padescen en las cárceles..., Toledo, Miguel Ferrer, 1564, fols. 33v.-38r.

44 Vid. Michèle Guillemont, op. cit., p. 78.

${ }^{45}$ Sobre la importancia concedida al honor y a la fama en la Edad Moderna, vid. Debora SHUGER, Censorship and Cultural Sensibility. The Regulation of Language in Tudor-Stuart England, Filadelfia, University of Pennsylvania Press, 2006, y Keith Thomas, The Ends of Life. Roads to Fulfillment in Early Modern England, Oxford, Oxford University Press, 2009, pp. 147-186.

46 «Les blasphemes quil a prononcé et escript contre Dieu», «les heresies dont il a infecté le monde», «les mechantes calumnies et faulses diffamations quil a publié contre les vrais serviteurs de Dieu, et notamment contre Mr. Calvin duquel ledict proposant es tenu de maintenir lhonneur «, «et aussi a cause du blasme et deshonneur qui pourroit avenir a leglise de Geneve pource que ledict Servet condamne par especial la doctrine quon y presche.» (Calv. Op., VIII, p. 735).

Hispania Sacra, LXII

125, enero-junio 2010, 181-211, ISSN: 0018-215-X 
IMPOSTURAS

Si algo llama poderosamente la atención es la insistencia con que a lo largo del debate Servet se dirigió a Calvino con el apodo de Simón el Mago, cuando no simplemente Mago. En medio de sus airadas imprecaciones, Servet deslizó en su discurso el nombre de ese personaje legendario en no menos de veintidós ocasiones. Par el español, Calvino era un falso profeta, reencarnación o personificación del impostor bíblico por excelencia. Algunos ejemplos aislados resultan expresivos por sí mismos: «iOh, Simón el Mago, embrujado!». ${ }^{47}$ «Tú, con Simón el Mago, niegas esta deidad de las almas».48 «Seguidor de Simón el Mago [...], a negar que eres otro Simón el Mago ni siquiera te atreves».49 «Tú vomitas, como Simón el Mago, con ánimo destructor en la carne de Cristo».50 «Este hereje, Simón el Mago, le tiene continuo odio a la carne de Cristo».51 «Júzguente a ti, mago, fantasma sin verdad alguna!».52

Las constantes alusiones a la figura de Simón el Mago no reflejaban una simple obsesión de Servet, ni tampoco una invención original suya. Por el contrario, la fuerza expresiva del recurso retórico se basaba precisamente en las arraigadas asociaciones con la mentira que aquel nombre evocaba todavía para muchos hombres y mujeres del siglo XVI. Según una leyenda muy extendida, en el siglo I de nuestra era el mago Simón ${ }^{53}$ había sido un líder religioso del gnosticismo muy famoso en Samaria por sus milagros extraordinarios, así como por el hecho de denominarse a sí mismo «potencia de Dios». 54 Pese a todo, tal y como narraban los Hechos de los Apóstoles, Felipe el Evangelista había logrado que se convirtiera al cristianismo. Pero la impureza de su fe pronto se puso de manifiesto cuando, al llegar Pedro y Juan a predicar a Samaria, Simón les ofreció dinero a cambio del poder de transmitir el Espíritu Santo, proposición que ambos apóstoles rechazaron escandalizados. De aquí procede el término «simonía» que, en un sentido estricto, se refiere a la venta de oficios eclesiásticos, pero en un sentido más general, designa el hecho de negociar con lo espiritual. ${ }^{55}$

$47 \ll$ O Simonem Magum, fascinatum hominem» (Calv. op., VIII, p. 527).

48 «Hanc animae deitatem et tu cum Simone Mago negas» (Calv. op., VIII, p. 533).

49 «Simonis Magi sectatorem [...] Simonem Magum te negare non audes» (Calv. op., VIII, p. 535).

50 «Exitiali spiritu cum Simone Mago in carnem Christi stomacharis» (Calv. op., VIII, p. 539).

51 «Haereticus hic Simon Magus semper in carnem Christi spirit odia» (Calv. op., VIII, p. 540).

52 «Expendant te magum, phantasma absque veritate aliqua» (Calv. op., VIII, p. 546).

53 Sobre la figura de Simón el Mago, vid. E. M. Butler, El mito del mago, Cambridge, Cambridge University Press, 1997, [1 $1^{\text {a }}$ ed., 1948], pp. 105-118; Valerie I. J. FLINT, The Rise of Magic in Early Medieval Europe, Oxford, Clarendon Press, 1991, pp. 338-344, y Mark EDwARDs, «Simon Magus, the Bad Samaritan», en M. J. Edwards y Simon SwaIn (eds.), Portraits. Biographical Representation in the Greek and Latin Literature of the Roman Empire, Oxford, Clarendon Press, 1997, pp. 69-91.

${ }^{54}$ En griego, dinamis. Vid. Mark EDWARDS, op. cit., p. 71.

55 Vid. Hechos 8:9-24. 
Las leyendas sobre Simón el Mago se multiplicaron, sobre todo durante los siglos II y III, ${ }^{56}$ pero lo que resulta más destacable es que su celebridad no disminuyó con el paso de los tiempos. Por el contrario, aunque su carácter fuera transformándose inevitablemente, a medida que se escribía sobre él, su fama continuó creciendo, al tiempo que se identificaba progresivamente con el contrapeso o contraejemplo de la verdadera doctrina. A finales de la Edad Media, su sola mención había acabado por convertirse en un auténtico «nombre de guerra» y su figura en uno de los dos prototipos del Anticristo, en este caso el de charlatán o falso profeta. El otro modelo era el tirano. ${ }^{57}$ Como insistían en señalar quienes se esforzaban en combatirle, a diferencia de los sermones y milagros de Cristo, las enseñanzas de Simón eran falsas, y sus milagros, meros trucos. Ambas cosas hacían de él no sólo un hereje común sino, por encima de todo, un mentiroso redomado.

Para comprender hasta qué punto las continuas menciones a Simón el Mago en el debate que tuvo lugar entre Calvino y Servet suponían la transposición de un mito de la Antigüedad clásica hasta la arena efervescente de la Reforma, resulta necesario referirse al relato del enfrentamiento entre el mago Simón y el apóstol Pedro, tal y como aparece referido en los Hechos apócrifos de éste. En esa versión, el astuto mago había abandonado Samaria y viajado hasta la misma Roma para predicar sus doctrinas y representar sus trucos. Tuvo tal éxito que muchos habitantes de la ciudad consideraban al apóstol Pablo un hechicero y un mentiroso, comparando sus habilidades con las de aquél. La fama de Simón se extendía no sólo entre el pueblo llano, sino también entre miembros de la élite política, como el senador Marcelo, en cuya casa se alojaba. Ante tal situación de extremo peligro para la propagación del cristianismo, el apóstol Pedro había decidido acudir también a Roma, dispuesto a enfrentarse cara a cara con Simón y, de este modo, recuperar la confianza y el apoyo de los volubles romanos. Para probar la falsedad de Simón, Pedro le había retado a participar en una competición de hazañas sobrenaturales.

Tras varias pruebas en las que Pedro consiguió mostrar su superioridad -haciendo hablar primero a un perro y después a un lactante de siete meses, devolviendo la vista a varias viudas ancianas, etc.-, el momento culminante llegó cuando Simón resucitó aparentemente a un muchacho mediante varios de sus trucos. No obstante, Pedro no sólo los descubría poniendo de manifiesto el fraude ante todos los presentes, sino que, con la ayuda de Dios, él mismo resucitó verdaderamente al muchacho:

\footnotetext{
${ }^{56}$ De hecho, a lo largo de estos dos siglos aparecerá mencionado no sólo en los Hechos apócrifos de Pedro, sino también en las obras patrísticas de Justino Mártir, Ireneo de Lyon e Hipólito, así como en la llamada «literatura clementina». Vid. Antonio PIÑEIRO y Gonzalo del CERRo (eds.), Hechos apócrifos de los apóstoles, vol. I («Hechos de Andrés, Juan y Pedro»), Madrid, BAC, 2004.

57 Vid. Mark EDWARDS, op. cit., p. 78.
} 
«Desde aquel momento, la gente, postrada a sus pies, adoraba a Pedro como a un dios [...]. Pero Simón, el mago, pasados unos pocos días, prometió a la plebe que dejaría convicto a Pedro de no creer en el Dios verdadero, sino en uno falso. Realizaba muchos actos de magia, pero los discípulos, bien asentados ya en la fe, se mofaban de él [...]. Pedro seguía todas sus acciones y lo refutaba ante los espectadores. Simón quedaba en mal lugar, y los romanos se burlaban y desconfiaban de él, ya que no lograba cumplir lo que prometía».58

Así las cosas, Simón, en un último intento desesperado para convencer a los romanos de su poderío, se lanzó a volar por los aires dejando admirados a quienes lo contemplaban. Pero entonces Pedro solicitó la ayuda divina para hacerlo caer, ya que de otro modo se arriesgaba a perder todo el crédito conseguido anteriormente:

«Simón se colocó en un lugar elevado y [...] ascendió en el aire, y todos veían cómo volaba sobre Roma, sobre sus templos y colinas, mientras los fieles miraban a Pedro. Éste, al contemplar el asombroso espectáculo, clamó al señor Jesucristo: - Si permites que este hombre realice lo que intenta, todos los que han creído en ti, se escandalizarán ahora [...]. Apresura, Señor, tu gracia: caiga Simón desde arriba y quede inútil. Que no muera, pero no pueda hacer nada con su pierna rota por tres lugares. Entonces lo lapidaron y cada uno se volvió a su casa. Por lo demás, todos creyeron en Pedro».59

Tras su fatal caída, y pese a ser apedreado, la leyenda del «mago con mentalidad de Ícaro» ${ }^{60}$ no terminaba ahí, pues «en medio de la desgracia encontró a algunas personas que lo trasladaron de noche sobre unas parihuelas desde Roma a Aricia». Finalmente, tal y como rezaba el texto apócrifo, en su camino hacia Oriente, «fue conducido a Terracina, a casa de un cierto Cástor, expulsado de Roma bajo acusación de artes mágicas. Allí, tras amputarle (la pierna) halló su fin Simón, ángel del diablo». ${ }^{61}$

Según otra versión del mismo relato, escrita en el siglo XIII por Jacopo de la Voragine en su Legenda aurea, «por aquel tiempo había en Jerusalén un mago llamado Simón, que aseguraba ser la verdad suprema [...] este mago [...] quiso sostener un debate público con San Pedro, y prometió demostrar a los asistentes que él era efectivamente Dios [...]. San Pedro confundió a su arrogante rival poniendo de manifiesto su impostura». El emperador Nerón «sentía hacia Simón un entusiasmo indescriptible», pero «Pedro intentó hacer ver a Nerón que así como en Cristo coexisten dos naturalezas, la divina y la humana, en aquel pernicioso mago coexistían dos sustancias: la del hombre y la del diablo». La superioridad de Pedro volvía a avalarse también en esta versión por la caída del

\footnotetext{
58 Vid. «Hechos de Pedro», en Hechos apócrifos de los apóstoles, op. cit., pp. 639-645.

59 Ibidem, p. 647.

60 Vid. E. M. ButLer, op. cit., p. 112.

61 Vid. «Hechos de Pedro», op. cit., p. 649.
} 
mago, el cual, nada más chocar contra el suelo al dejar de sostenerle «los demonios que lo llevaban volando por el aire», se rompía la cabeza, quedando muerto al instante. ${ }^{62}$

Lo interesante de las diferentes versiones de la leyenda de Simón no radica tanto en la variedad de anécdotas como en el hecho de reflejar la transformación de los valores, expectativas y actitudes de la Iglesia, desde sus comienzos hasta la época misma de la Reforma. Si en su más temprana introducción a la literatura occidental, el mago Simón se presenta como un potente rival de la Iglesia misionera (se llama a sí mismo «fuerza» $\mathrm{o}$ «poder»), con el tiempo se subrayará su condición de impostor (en el siglo XIII se autodenomina «verdad suprema», para demostrarse que personifica lo contrario). Si a comienzos de nuestra era, el apóstol Pedro decide perdonarle la vida, en el siglo XIII la compasión por el enemigo, cada vez más identificado con el mismo diablo, ha desaparecido, y Simón queda fulminado al instante. Tal es el espíritu que se resume en las palabras con que Pedro se dirige al mago en La leyenda dorada: «No esperes que te ocurra nada bueno mientras sigas siendo la encarnación de la mentira; porque eso eres tú, una mentira viviente: mentira es todo lo que haces, y mentira todo lo que dices». .3

Calvino representaba para Servet el falso conocimiento característico de los magos, fundado en el engaño deliberado mediante la utilización de todo tipo de trucos, en este caso dialécticos. La figura de Simón -antepasado de otros magos famosos de la tradición cristiana como Teófilo, Cipriano o el mismo Fausto-64 le servía a la perfección para dar rienda suelta a su ira, apoyada en el sentimiento de hallarse frente al negativo de la verdad que él se había propuesto sostener. «Desvergonzado tergiversador, abiertamente mientes!», 65 «iTodo lo perviertes sin vergüenza!», ${ }^{66}$ «iMientes!», 67 «iBromeas!», ${ }^{68}{ }{ }_{i} \mathrm{O}$ Oh, bribón enceguecido!», 69 «Satanás te ha cegado los ojos», ${ }^{7}$, «Tú sólo eres el falsario», ${ }^{71}$ «iSimón el Mago, siempre infame y perverso!».72 Son tan solo algunos ejemplos de las constantes arremetidas de Servet contra su adversario.

${ }^{62}$ Vid. Santiago de la VoRÁGINe, Leyenda dorada, Madrid, Alianza, 1982, vol. I, pp. 346-357.

${ }^{63}$ Ibidem, p. 350.

${ }^{64} \mathrm{Al}$ igual que en el caso de Simón, la falsedad de los poderes mágicos de Fausto se demuestra por su incapacidad para resucitar a los muertos. Sobre las figuras de Teófilo, Cipriano y Fausto como derivaciones de la leyenda de Simón, vid. Mark EDWARDS, op. cit., pp. 89-91.

65 «O impudentem tergiversatorem, mentiris palam» (Calv. op., VIII, p. 523).

66 «Tu omnia impudenter in malam partem vertis» (Calv. op., VIII, p. 521).

67 «Mentiris» (Calv. op., VIII, pp. 521-553).

68 «Nugaris» (Calv. op., VIII, p. 522).

69 «O nebulonem excaecatissimum» (Calv. op., VIII, p. 523).

70 «Satanas tibi oculos clausit» (Calv. op., VIII, p. 523).

71 «Tu solus falso» (Calv. op., VIII, p. 524).

72 «Simon magus semper nequam et perversus» (Calv. op., VIII, p. 524). 
Los desprecios intercambiados por Servet y Calvino no se justificaban únicamente en su visión opuesta de las verdades religiosas que cada uno se sentía llamado a defender, sino que se hacían extensivos al alcance moral de la persona del contrario. Tal y como correspondía a la identificación de la verdad con el bien (y, en consecuencia, de la falsedad con el mal) característica de la epistemología ética de la época, ${ }^{73}$ Servet se dirigió a Calvino acusándolo de ignorante, pero también de malvado, hasta el punto de llegar incluso a despojarlo de su identidad humana, mediante el recurso a la animalización. Uno de los insultos más frecuentes en el contexto de las polémicas religiosas de la Edad Moderna era precisamente el de perro. ${ }^{74}$ « ¿No te avergüienza mencionar tantas cosas y no aportar ninguna razón para reprobarlas? ¿Con sólo tus ladridos, perro, piensas aturdir los oídos de los jueces»?, ${ }^{75}$ exclamaba Servet. Y para subrayar el menosprecio que las doctrinas de Calvino le inspiraban, en otra ocasión lo calificaba de ridículo ratón. ${ }^{76}$

En cuanto a Calvino, la mayoría de los calificativos contra Servet se concentraron en su intrínseca falsedad. ${ }^{77}$ No obstante, en vista de la arrogancia, la insolencia y la obstinación mostradas por el español, ${ }^{78}$ la acusación de falsario se acompañó de otros epítetos de índole estrictamente ética como los de canalla ${ }^{79}$ o corruptor. ${ }^{80}$ Este último adjetivo no sólo se aplicó en un sentido literal, en tanto que presunto falseador de las Escrituras, sino también en el sentido más general de pervertidor de la moral y las costumbres. Por lo que respecta a las alusiones sobre la locura de

73 «The problems attaching to true and false in the field of vision were clearly homologous to those attaching to good and bad in the field ot ethics». Vid. Stuart CLARK, Vanities of the Eye. Vision in Eealy Modern European Culture, Oxford, Oxford University Press, 2007, p. 280.

${ }^{74}$ Las resonancias religiosas del epíteto injurioso «perro» (símbolo de impureza y apostasía) se reflejan en la Biblia en dos ejemplos significativos: la Epístola de San Pablo a los Filpenses 3:2 («Guardaos de los perros»), y Proverbios 26:11 («Como perro que vuelve a su vómito, así es el necio que vuelve a su necedad»). Vid. Michèle GuILlemont, op. cit., vol. II, p. 424.

75 «Non te pudet, tanta hic referre, et nullam improbationis rationem adducere? Solo tuo canino latratu putas iudicium aures esse obtundendas?» (Calv. op., VIII, p. 516).

76 «Ridiculus mus» (Calv. op., VIII, p. 527).

77 «Falsarius deprehendetur» (El falsario será atrapado); «Scelesta hominis falsitas» (La criminal falsedad de este hombre); «Maior est Serveti impudentia [...] dum in tan clara luce fumos spargere non dubitat» (Es desvergüenza suma de Servet [...] que ante tanta luz no dude en esparcir humaredas); «Tanta est Serveti improbitas, ut colore fucare velit exsecrandum suum errorrem» (Es tanta la maldad de Servet que quiere colorear su execrable error). Vid. Calv. op., VIII, pp. 523-526.

78 «Mira certe hominis arrogancia» (Admirable arrogancia de este hombre); «Eadem arrogantia nobis caninum latratum hic exprobrat» (Con igual arrogancia nos echa en cara ladridos); »Quam caeca sit ius obstinatio» (¡Cuán ciega es su obstinación!). Vid. Calv. op., VIII, pp. 538, 540 y 542.

79 «Ventosus nebulo» (Presumido canalla). Vid. Calv. op., VIII, p. 527.

80 «Quam nequiter verba mutet iste corruptor» (Cuán viciosamente muda las palabras este corruptor); «Ita elabi non potest quin omnia pietatis principia corrupterit» (Y así, no puede por menos de corromper todos los principios de la religión); «Hunc infaustum hominem nullum doctrinae caput intactum a suis corruptelis reliquisse» (Este desgraciado no ha dejado ni un solo punto de doctrina intacto de sus corrupciones). Vid. Calv. op., VIII, pp. 532, 541 y 552. 
Servet, en repetidas ocasiones Calvino insistió en la gravedad de sus delirios y en su carencia de sentido común, ${ }^{81}$ lo que suponía una táctica más dirigida a la desacreditación del reo, al que se presentó como incapaz de razonar. No en vano el término «locura», cargado de resonancias tan amplias como ambiguas, solía utilizarse por los reformadores religiosos de la época para aplicarlo a sus adversarios y, en general, a cuantos se consideraban viciosos o pecadores..$^{82}$

La exasperación de Calvino se manifestó especialmente en los momentos finales de la discusión, en los que Servet fue sucesivamente calificado de maniqueo ${ }^{83}$ y pelagiano ${ }^{84}$ comparado con los cátaros ${ }^{85} \mathrm{y}$ finalmente acusado de libertino. ${ }^{86} \mathrm{De}$ acuerdo con las últimas líneas escritas por Calvino a propósito del reo, Servet

«Demuele la ley de Dios para que el gusto de cada uno sea su norma de vida. Separa la fe y sus promesas. Debilita la justificación gratuita de Dios. Priva de toda gracia a los Padres que murieron bajo la ley antigua, como si hubieran vivido igual que obesos puercos. Con su fantasioso concepto de la regeneración, precipita a los simples en los lazos del demonio y, respecto a él, es un libertino [...]. En conclusión, quienquiera que juzgue verdadera y prudentemente reconocerá que la meta de este hombre ha sido apagar la luz de la sana doctrina y destruir toda religión». 87

Resulta evidente que, por detrás de la pantalla de descalificaciones mutuas, lo que se traslucía no era una mera competición de insultos, sino un duelo entre

81 «Pudendum in modum delirat» (Delira de modo vergonzoso); «Serveti delirio» (El delirio de Servet); «Hominem communi sensu destitui, dum ita frigide nugatur» (Este hombre carece de sentido común por charlatanear tan fríamente). Vid. Calv. op., VIII, pp. 526, 529 y 534.

82 «Used as frequently as the charge of being a false brother, the accusation of madness clearly had other tactical advantages as well. Luther hurled this charge, not just at former disciples [...], but at the Turks, the Jews, Catholics in general and the pope in particular, at monks, scholastics, Arians, Epicureans, atheists, fatalists, Stoics, antinomians, visionary saints, despotic princes, and the many towering examples of wickedness». Vid. Erik MideLForT, op. cit., pp. 83-84. Sobre la tendencia a considerar la locura como pecado en la Edad Moderna, vid. María TAUSIET, «Taming Madness: Moral Discourse and Allegory in Early Modern Spain», History, 2009, vol. 94, 3, nº 315 (2009), pp. 279-293.

83 «Mira hominis ferocia, quod cum Simone mago delirare exprobat quicunque nolunt esse cum eo Manichaei» (Extraña ferocidad de este hombre, reprobar con Simón el Mago a quienes se niegan a ser con él maniqueos). Vid. Calv. op., VIII, p. 549. «Manichaeum gloriatur, et se reprehendi non sustinet» (Se gloría de ser un maniqueo y no tolera que le reprendan). Vid. Calv. op., VIII, p. 551.

84 «In libero arbitrio Pelagianus est» (En cuanto al libre albedrío, es pelagiano). Vid. Calv. op., VIII, p. 552.

85 «Perfectionem iustitiae statuit, ut Cathari» (Pone por meta la santidad perfecta, como los cátaros). Vid. Calv. op., VIII, p. 552.

86 «Libertinus est» (Es un libertino). Vid. Calv. op., VIII, p. 552.

87 «Legem Dei sic abolet, ut cuique suus afflatus sit vivendi regula. Fidem a promissionibus discerpit. Gratuitam fidei iustificationem labefactat. Patres, qui sub lege mortui sunt, omni gratia spirituali privat, quiasi instar porcorum saginati in terra fuerint. Sua phantastica regeneratione simplices in diaboli laqueos praecipitat, planeque hac in parte Libertinus est [...] Quisquis ergo vere et prudenter reputabit, hunc illi scopum fuisse agnoscet, ut luce sanae doctrinae exstincta totam religionem everteret.» (Calv. op., VIII, p. 553).

Hispania Sacra, LXII

125, enero-junio 2010, 181-211, ISSN: 0018-215-X 
dos visiones del mundo antitéticas. La violencia verbal de ambos contendientes ha de ser interpretada, por tanto, como un arma más en el denodado combate espiritual librado por ambos teólogos en defensa de sus ideales. Desde nuestra perspectiva contemporánea, los conceptos que en el fondo estaban debatiéndose pueden servir como modelos culturales de dos períodos históricos sucesivos, que a mediados del siglo XVI entrechocaron con una fuerza inusitada: el final de la Edad Media, representado en la figura de Calvino, y la explosión del Renacimiento humanista, encarnado en Servet. Pese a las dificultades de comprensión de un discurso teológico enmarañado, salpicado de injurias y a menudo malinterpretado por considerarse centrado en el supuesto antitrinitarismo de Servet, lo que estaba poniéndose en cuestión no era sino una nueva definición de la naturaleza humana anclada en lo divino, y viceversa.

\section{COSMOVISIONES}

Como ya ocurriera en su tiempo, la polémica entre Servet y Calvino resulta oscura y prácticamente incomprensible para el lector actual sin tener en cuenta ciertas premisas. ${ }^{88} \mathrm{~A}$ modo de presagio del enfrentamiento final entre los dos teólogos conviene subrayar el hecho de que el tratado más importante de Servet, Christianismi restitutio (Restitución del cristianismo), publicado en el año de su muerte, desde su mismo título venía a ser una réplica a la principal obra de Calvino, Institutio christianae religionis (Institución de la religión cristiana), publicada diecisiete años antes, esto es, en 1536. Restitutio contra Institutio o, dicho de otro modo, devolver al cristianismo su sentido original, frente a la progresiva institucionalización llevada a cabo tanto en el bando católico como en el protestante, era el programa mesiánico que Servet se proponía llevar a cabo, convencido de hallarse en la obligación de enseñar la «verdad» que se le había «revelado».

Para restituir su simplicidad al cristianismo primitivo, deformado a lo largo de los siglos por las especulaciones de los teólogos, los abusos del papado, las jerarquías eclesiásticas, la imparable definición de dogmas, etc., el método propuesto por Servet consistía en volver a leer la Biblia partiendo únicamente de lo que en ella estaba escrito, sin dar por sentada ninguna interpretación posterior. En ese sentido, su aproximación al cristianismo, al igual que la de otros célebres humanistas de su tiempo -entre ellos, Erasmo de Rotterdam- era esencialmente filológica, historiográfica y, prima facie, relativista. No obstante, no sólo

${ }^{88}$ Servet era ya considerado por sus contemporáneos como un autor oscuro y difícil, llegando incluso a ser equivocadamente acusado de arriano, por creerse que negaba la naturaleza divina de Cristo. Vid. Luisa SimonutTi, «Après Michel Servet: Hérésie et Antitrinitarisme», en Valentine ZuBER (ed.), Michel Servet (1511-1553). Hérésie et pluralisme su XVI e au XXIe siècle, París, Honoré Champion, 2007, pp. 189-190. 
su acusada personalidad y su carácter apasionado, sino también un buen número de textos, dada su formación amplísima, iban a predisponerle a favor de ciertas posturas. Entre las lecturas mencionadas a lo largo de su obra, conviene destacar una cincuentena de autores griegos y latinos, el Corán, la literatura rabínica, los Padres de la Iglesia -en especial, Ireneo y Tertuliano- y los filósofos escolásticos, pero sobre todo los nominalistas que desde el siglo XIV habían empezado a poner en entredicho el rígido armazón lógico de la escolástica, al afirmar que sólo existen los individuos y que, por tanto, los universales o esencias no son sino nombres inventados, producto de la mente humana. ${ }^{89}$

La filosofía de Servet partía, en efecto, de un individuo, el hombre histórico Jesucristo. Siguiendo el método científico moderno consistente en deducir a partir de los objetos sensibles, el Hijo de Dios, en tanto que imagen de su Padre, ofrecía al intelecto humano la única posibilidad de formarse una noción del Deus absconditus, del que por definición no sabemos nada. El énfasis en la humanidad de Cristo, sin dejar por ello de ser Dios, llevó a Servet a replantearse la noción de Trinidad tal y como se había expresado en el concilio de Nicea en 325, y con mayor precisión en el de Calcedonia en 450. Su definición de la Trinidad había sido inicialmente adoptada como una fórmula para explicar la encarnación de Dios en Jesucristo, frente al estricto monoteísmo defendido por judíos y musulmanes, según el cual Dios es exclusivamente uno.

Para los cristianos Dios era sólo uno pero, al mismo tiempo, Cristo también era Dios: ¿no habría en realidad dos dioses? Y si el Espíritu Santo personalizaba asimismo a Dios, ¿no serían más bien tres? Como afirma Roland Bainton, «la solución consistió en admitir simultáneamente una unidad y una trinidad en Dios, una diversidad dentro de la unidad, un pluralismo dentro del monismo. La palabra escogida en latín para expresar la unidad fue substantia, y para expresar la trinidad persona»..$^{0}$ De este modo, se defendió como dogma que Dios era uno y trino, dado que las tres personas, Padre, Hijo y Espíritu Santo, compartían una misma sustancia o esencia.

Para Servet, todo ello no era más que una invención sobre la cual la Biblia no decía absolutamente nada, y que sólo podía defenderse por medio de sofisterías. En su opinión, la Trinidad divina había sido malinterpretada, al entenderse el término persona como ser o esencia (tres seres en uno), y no como aspecto (formas diferentes de manifestarse o disponerse temporalmente el Dios único). La idea de sustancia compartida (en griego, homoousios) ${ }^{91}$ implicaba que Pa-

${ }^{89}$ Vid. Rolande-Michelle BÉNIN, «Traduire Servet», en Valentine ZUBER (ed.), op. cit., pp. 89-108.

90 «The solution was to posit both a oneness and a threeness in God, a diversity within unity, a pluralism within monism. The word chosen in Latin to express the oneness was substance, and the word for the threeness was person». Vid Roland H. BAINTON, Hunted Heretic..., p. 22.

${ }^{91}$ Homoousios, derivado de homo (misma) y ousios (sustancia). 
dre, Hijo y Espíritu Santo eran eternos e intemporales; sin embargo, Jesucristo había nacido en un momento histórico concreto y se hallaba sujeto a la temporalidad característica de los seres humanos. Así, el Hijo, en tanto que Verbo (Logos) o idea, sí podía ser eterno, pero en tanto que hombre, no.

Las diferentes visiones de Calvino y Servet acerca de la Trinidad, derivadas de dos formas opuestas de entender la humanidad de Cristo, marcaron desde el comienzo el tono del debate entre ambos. Servet defendía que el término hijo en la Sagrada Escritura se atribuía siempre al hombre hijo, mientras que Calvino mantenía que «el término Hijo de Dios es ajeno a la naturaleza humana».92 Servet repetía una y otra vez que Cristo era, por encima de todo, un hombre, lo que descartaba su existencia eterna y atemporal. Calvino insistía, a su vez, en que el Hijo de Dios era eterno, pues había sido engendrado por el Padre antes de los tiempos, ${ }^{93}$ lo que confirmaba la doctrina niceana de la Trinidad. Según sus propias palabras, «el Hijo siempre existió, como el Padre» y «son distintos porque se interrelacionan». ${ }^{44}$ Para Servet, sin embargo, las menciones bíblicas al Verbo y al Espíritu no se referían a entidades distintas, sino a disposiciones de Dios». .5

La importancia concedida por Servet a tales sutilezas radicaba en su ardiente defensa de la humanidad de Cristo, y con ella de la humanidad en su conjunto. La única certeza de la que partían todas sus reflexiones era que Jesús había sido un hombre, ya que así era como las escrituras se referían a él, sin ponerlo nunca en duda. Aunque en ocasiones se le llamaba también Dios e incluso Hijo de Dios, «de ser Dios, sólo podría serlo en un sentido en el que el hombre pueda ser capaz de ser Dios». ${ }^{96} \mathrm{Su}$ concepto optimista del hombre y de la relación hombre-Dios era por completo opuesto al de Calvino. Para Servet, en realidad no existía una frontera entre los hombres y Dios, pues Dios vivía en el interior de cada hombre en forma de Espíritu Santo. ${ }^{97}$ De ese modo, la humanidad y la

\footnotetext{
92 «Nomen filii Dei habetur extra humanae naturae respectum» (Calv. op., VIII, p. 520).

93 «Negaret a patre genitum ante saecula: et plus quam atrocibus conviciis proscinderet omnes pios, qui fatentur aeternum fuisse Dei filium» (Calv. op., VIII, p. 521).

94 «Filium semper fuisse, quia pater fuit: et distinctos esse, quia relative inter se habeant» (Calv. op., VIII, p. 527).

95 «Scripturas de verbo et spiritu ait non referri ad res distinctas, sed ad dispositiones Dei» (Calv. op., VIII, p. 513).

96 «If he were God, he could be God only in a sense in which man is capable of being God». Vid. BaInTON, Hunted Heretic... (Calv. op., VIII, p. 46).

97 «Dios mismo es nuestro espíritu que habita en nosotros, y éste es el Espíritu Santo dentro de nosotros. Con ello afirmamos que hay latente en nuestro espíritu cierta energía activa, cierto sentido divino, una divinidad latente que sopla donde se le escucha, y yo oigo su voz, y no sé de dónde viene ni adónde va». Vid. BAINTON, Servet, el hereje perseguido..., p. 60. («God himself is our spirit dwelling in us, and this is the Holy Spirit within us. In this we testify that there is in our spirit a certain working latent energy, a certain heavenly sense, a latent divinity and it bloweth where it listeth and I hear its voice and I know not whence it comes nor whither it goes», Vid. BAInTON, Hunted Heretic..., p. 47).
} 
divinidad no se excluían mutuamente, y Cristo podía ser Dios sin dejar de ser hombre.

El humanismo optimista de Servet le llevaba a identificar al hombre con Cristo y, a través de él, con Dios. Tal y como afirmaba en su Restitutio: «Nuestro hombre interior no es sino Cristo mismo. Lo cual no equivale a decir que somos lo mismo que Cristo, pues nadie es lo mismo que otra persona. Pero Cristo nos comunica su gloria [...]. Nuestro hombre interior consiste en el elemento divino, de Cristo, y en el humano, de nuestra naturaleza, de modo que con toda propiedad se nos llama partícipes de la naturaleza divina [...]. Nuestro hombre interior es realmente celestial [...]. Nuestro hombre interior es Dios, como Cristo es Dios y el Espíritu Santo es Dios».98

Desde el punto de vista de Calvino, mezclar a Dios y al hombre era algo no sólo lógicamente absurdo, sino sobre todo profundamente impío, ya que suponía identificar a Dios con algo corruptible, sujeto a los vicios y flaquezas de la carne. Para Calvino, lo que estaba en juego era la majestad de Dios, de ahí que calificase de delirio la convicción de Servet de que la carne de Cristo participaba de la sustancia de Dios. En defensa de lo contrario afirmaba con contundencia: «A Dios es necesario creerlo inmutable, e informable y eterno».99 Para Servet, Jesucristo era eterno, pero únicamente en el sentido en que no sólo el hombre, sino todo lo existente participaba de la divinidad. Interrogado por Calvino sobre cómo entendía que Cristo era Dios eterno, su respuesta había sido: «es eterno igual que todas las otras cosas, de las cuales es Él el primero en orden». ${ }^{100}$ Calvino había despreciado esas palabras como sacrílegas, ya que suponían «una eternidad imaginaria que es común tanto a Cristo como a las piedras».101

A medida que avanzaba el debate, el tema de la Trinidad, que había iniciado la refriega y que parecía constituir el principal motivo de enfrentamiento entre los dos, empezó a dejar paso a lo que, en el fondo, constituía la incompatibilidad esencial entre ambos. Al sentido de la inmanencia divina defendido por Servet, según el cual Dios se hallaba presente en todo (desde las piedras hasta

98 Vid. BAInTON, Servet, el hereje perseguido..., pp. 146-147. «Our inward man is nothing but Christ himself. This is not to say that we are equal to Christ; for that matter we are not equal to each other. But Christ communicates to us His glory [...] Our inward consists of the divine element from Christ and the human form from our nature so that truly we are said to be participants of the divine nature [...] Our inward man is truly heavenly [...] Our inward man is God as Christ is God and the Holy Spirit is God.» Vid. BainTon, Hunted Heretic..., pp. 138-139.

99 «Serveti delirio carnem Christi esse ex Dei substantia [...] Deum enim inmutabilem et informabilem credi necesse est, ut et aeternum» (Calv. op., VIII, p. 529).

100 «Aeternum fuisse Christum, sicuti res alias omnes: quamvis ordine primum esse Christum dicat» (Calv. op., VIII, p. 547).

101 «Ad tam sacrilegam vocem quum omnes piae mentes exhorreant [...] Nempe imaginariam quandam aeternitatem quae Christo et lapidibus sit commubis» (Calv. op., VIII, p. 547).

Hispania Sacra, LXII

125, enero-junio 2010, 181-211, ISSN: 0018-215-X 
las almas), se oponía a la idea de trascendencia divina defendida por Calvino, para quien Dios, dada su incomparable perfección y superioridad, se encontraba mucho más allá del mundo material y, en consecuencia, muy alejado también del hombre y, en particular, de su inclinación a los pecados de la carne. Ambos puntos de vista, llevados a su extremo, traían consigo infinitas implicaciones. Desde la inmanencia, el dogma de la encarnación divina, por ejemplo, no dejaba de ser un mero símbolo, pues la encarnación de Dios en la humanidad continuaría incesantemente. Partiendo del presupuesto de la deidad de las almas, también era posible interpretar que los hombres, como partícipes de lo divino, poseían un gran margen de libertad y poder de decisión, en contra de la doctrina de la predestinación defendida por Calvino. Según Servet, una de las enseñanzas del apóstol San Pedro, contra Simón el Mago y sus discípulos, era «que tenemos insertada en nosotros la divinidad, por cuyo motivo hay en nosotros alguna libertad de albedrío [...]. Y no otra cosa enseña Ireneo, defendiendo siempre el libre albedrío contra esos magos. Nadie jamás enseñó otra cosa en el cristianismo sino el mago Calvino». ${ }^{102}$

Desde el punto de vista de Servet, la magia de Calvino se cifraba no sólo en su dialéctica engañosa sino, muy especialmente, en su doctrina de la predestinación: «iTú, miserable, ilusionado por Simón el Mago [...] proclamando contra el libre albedrío el siervo arbitrio, nos haces troncos y piedras!». ${ }^{103}$ Para Servet, otra manifestación de la magia, que insistía en atribuir a Calvino, era su defensa, compartida con los católicos, de la gracia como un don divino que santificaba al hombre desde fuera y no desde su propia interioridad. A propósito de la gracia divina que, según Calvino, Dios Padre había infundido a la naturaleza humana de Cristo, exclamaba Servet: «¿Qué es lo que tú llamas gracia? ¿Una cualidad creada? No la hay en Cristo, sino la mismísima divinidad. Todas esas cualidades infusas son cosa de magia. Nos hacemos verdaderamente partícipes de la naturaleza divina, templo de Dios que verdaderamente habita en noSotros». ${ }^{104}$

Para Servet, Dios se expresaba en todo lo creado, sin ningún tipo de excepción. Desde los objetos inanimados a los espíritus más sutiles, pasando por los

102 «Contra Simonem magum et eius discipulus docet Petrus, esse nobis insitam divinitatem, cuius ratione est in nobis aliqua arbitrii libertas [...] Nec secus docet Irenaeus, semper contra magos liberum arbitrium defendens. Nemo unquam in christianismo aliter docuit, nisi Calvinus mago» (Calv. op., VIII, pp. 514 y 515 ).

103 «Tu miser a Simone mago illusus, id ignoras, ut servum arbitrium statuens, nos facias truncos et saxa» (Calv. op., VIII, p. 518).

104 «Quid tu gratiam vocas qualitatem creatam? Nulla talis est in Christo qualitas: sed ipsissima deitas. Magorum sunt tuae illae qualitates infusae. Nos participes vere sumus divinae naturae. Templum Dei nos vere inhabitantis» (Calv. op., VIII, p. 548). 
cuerpos mortales, incluido el de Cristo, ${ }^{105}$ ya estuvieran vivos o muertos, incluso en proceso de corrupción, ${ }^{106}$ todo participaba misteriosamente de lo divino: «En todas las cosas está Dios por esencia, presencia y potencia, y todas las sostiene». ${ }^{107}$ Esta convicción le había llevado al extremo de afirmar que «Dios lo llena todo, hasta el infierno». ${ }^{108}$ Según Calvino, que Dios estaba en todo resultaba indiscutible, pero «de ello no se sigue que en todas las criaturas haya divinidad sustancial». ${ }^{109}$ Para él, resultaba de todo punto inadmisible que, tal y como Servet había confesado durante su proceso, «hasta el suelo que pisamos con los pies, y los diablos, todo esté lleno de lo divino». ${ }^{110}$ Desde el punto de vista de Servet, el cerrilismo y la incomprensión de Calvino eran tales que, sin contener el desprecio que sus posturas le inspiraban, en ese momento llegó a calificarlo de archidemonio, lo cual no dejaba de constituir una burla irónica, teniendo en cuenta lo que estaba discutiéndose:

«Dijiste que moviendo el pie, tú no te mueves en Dios. Te moverás en Satanás, si no en Dios, en quien vivimos, nos movemos y somos. Aun siendo un archidemonio, te sigue sosteniendo Dios». ${ }^{111}$

La visión integradora de Servet, para quien tanto el cielo como el infierno se hallaban igualmente en manos de Dios, y el cuerpo podía ser tan divino como el espíritu, implicaba una fe en la unidad del mundo característica de los hombres del Renacimiento. Desde su perspectiva, como médico y teólogo a un tiempo, la realidad no admitía las líneas divisorias que Calvino pretendía imponerle: «Muchas cosas cuajan en una sola, al igual que los huesos, carne, nervios, alma, forma y espíritu constituyen la sustancia del hombre».112 Para Servet, to-

105 «Haereticus hic Simon magus semper in carnem Christi spirat odia» (Este hereje, Simón el Mago, le tiene continuo odio a la carne de Cristo»). Calv. op., VIII, p. 540.

106 «Exiliali spiritu tu cum Simone mago in carnem Christi stomacharis, quasi non suam illa in sepulcro habuerit divinitatem» (Tú vomitas, como Simón el Mago, con ánimo destructor en la carne de Cristo, como si en el sepulcro no hubiera divinidad). Calv. op., VIII, p. 539.

107 «In omnibus creaturis deitatem constituit etiam substantialem» (Calv. op., VIII, p. 506).

108 «Deus omnia implens, etiam ipsum infernum implent». Vid. Christianismi Restitutio $\left[1^{\text {a }}\right.$ ed., 1553], versión facsímil de la ed. de Christoph GOTTLIEB VON MURR, Nüremberg, 1790, por la casa editorial Minerva, Frankfurt am Main, 1966, p. 240.

109 «De eo nihil est controversiae, an sit Deus in omnibus per essentiam, praesentiam et potentiam, et an omnia sustentet. Sed hinc non sequitur in omnibus creaturis substantialem esse deitatem» (Calv. op., VIII, p. 550).

110 «Multo minus, quod ipse coram iudicibus confessus est, pavimentum, quod pedibus calcamus, deitatis esse particeps, et in diabolis omnia deorum esse plena» (Calv. op., VIII, p. 550).

111 «Pedem movens, dicebas te in Deo non moveri. Ergo in Satana movebaris: nos in Deo, in quo vivimus, movemur et sumus. Etiam si sis tu cacodaemon, adhuc tamen a Deo sustineris» (Calv. op., VIII, p. 550).

112 «Verum est, multa in unum ita coire; ut ossa, caro, nervi, anima, forma, spiritus in unam hominis substantiam coeunt» (Calv. op., VIII, p. 518).

Hispania Sacra, LXII

125, enero-junio 2010, 181-211, ISSN: 0018-215-X 
das las ciencias eran trascendentes, pues tanto la fisiología como la psicología, y no sólo la teología, al igual que el resto de disciplinas, conducían al conocimiento de Dios. Sólo así se explica su célebre descripción de la circulación de la sangre, a la que identificaba con el alma o el Espíritu Santo que, en su peregrinaje a lo largo del cuerpo, deifica a todos los hombres, o su interpretación de la respiración como aliento de Dios, cuya finalidad consiste precisamente en purificar la sangre. ${ }^{113}$

Según Calvino, tales mezclas se traducían únicamente en confusión y desorden o, citando su expresión literal, en «un inmenso laberinto de errores».114 Desde su visión de la naturaleza de Dios (trascendente y no inmanente) y del hombre (miserable y no divino, predestinado y no libre), el hecho de que Servet, además de todo lo anterior, se negara a admitir el bautismo infantil, por considerar que nadie peca mortalmente antes de los veinte años, iba a constituir la gota que colma el vaso y, pese a su aparente nimiedad, en comparación con lo ya discutido, un aspecto decisivo para decidir su condena. La inocencia radical atribuida por Servet a los niños y a los jóvenes ponía bajo sospecha la doctrina del pecado original, cuya formulación constituía el fundamento de la Redención y, en consecuencia, de la Encarnación divina. Ello remitía de nuevo a la Trinidad, lo que venía a cerrar el círculo, llevando la discusión a un callejón sin salida. ${ }^{115}$

\section{ERRORES Y CERTEZAS}

Del mismo modo que las ideas de Servet constituían para Calvino «un inmenso laberinto de errores», para Servet las doctrinas defendidas por Calvino eran fundamentalmente falsas. El concepto de «verdad religiosa», basado en la lógica matemática según la cual es posible distinguir lo verdadero de lo falso, condicionaba las creencias de la inmensa mayoría de los reformadores del siglo XVI: no en vano su principal tarea consistía en descubrir y proclamar las

\footnotetext{
113 Vid. BAInTON, Hunted Heretic..., pp. 124-127.

114 «Immenso errorum labyrintho» (Calv. op., VIII, p. 552).

115 Como resalta Roland H. BAINTON: «Es significativo que Servet fuera condenado finalmente sólo por dos cargos: su antitrinitarismo y su oposición al bautismo infantil. Nada hay en la sentencia sobre su aparente panteísmo y su pretendida negación de la inmortalidad [...], nada sobre su conducta moral, y nada, absolutamente nada, sobre delito político de ningún tipo. Al parecer, los jueces pensaron que estas acusaciones no habían quedado suficientemente demostradas. Servet murió como hereje», vid. BAINTON, Servet, el hereje perseguido..., p. 212. ( On only two counts, significantly, was Servetus condemned -namely, anti-Trinitarianism and anti-paedobaptism. There is nothing about pantheism and the denial of immortality [...] nothing about the moral offenses. There is absolutely nothing about any political offense. The judges apparently felt that these charges had not been substantiated. Servetus died as a heretic», vid. BAINTON, Hunted Heretic..., p. 207).
} 
«verdades» divinas frente a los «errores» diabólicos defendidos por sus oponentes. En palabras del propio Servet: «Todos me parecen tener parte de la verdad y parte de error, y cada cual espía el yerro ajeno, incapaz de ver el propio». ${ }^{116}$ Esta declaración de relativismo no le había impedido, sin embargo, publicar su primera obra bajo el significativo título Los errores de la Trinidad, ${ }^{117}$ como si estuviera tratando de una ciencia exacta.

Tal «espíritu de certeza», característico de los primeros tiempos de la Reforma, iba a encontrar en Calvino a su principal representante. Su grandiosa empresa descansaba en la asunción de que Dios puede ser conocido, de que es posible vislumbrar el plan divino y de que incluso los elegidos pueden llegar a ser reconocidos por ciertas pruebas tangibles. Para Calvino, la ecuación fe-conocimiento no admitía ninguna duda. Frente a la extrañeza que hoy nos produce el hecho de que, nada más morir Servet, fuera el mismo Calvino quien voluntariamente se encargara de publicar la feroz discusión en que el español le cubría de insultos, resulta necesario comprender que Calvino lo hizo armado de una seguridad aplastante en la verdad que le asistía. El título de la obra en que se inscribió el debate no puede ser más expresivo: Defensa de la Santísima Trinidad contra los prodigiosos errores del español Miguel Servet. ${ }^{118}$

Vistas las reacciones negativas que se produjeron en Suiza al conocerse la muerte de Servet y las numerosas críticas que se alzaron contra Calvino, más que una defensa de la Trinidad, el tratado venía a ser una defensa personal para explicar los motivos que le habían empujado a cumplir el deber sagrado de ordenar la condena del español, que no eran otros que sus certezas acerca de la naturaleza divina y del hombre. No obstante, como iba a poner de manifiesto Sebastián Castellio en su valiente réplica contra el libelo de Calvino, 119 tratándose de creencias, nadie posee el derecho de arrogarse la capacidad de juzgar dónde está el error, ya que todas las verdades religiosas son discutibles, y en realidad no sabemos nada, dada la oscuridad e imprecisión con que se expresa la Escritura. ${ }^{120}$ En ese sentido, Servet no habría cometido ningún crimen por el

${ }^{116}$ De iustitia et regno Christi $\left[1^{\mathrm{a}}\right.$ ed., 1532], ed. facsímil, Minerva, 1965, fols. 7b-8a. Vid. BAINTON, El hereje perseguido..., p. 79. («All seem to me to have a part of truth and a part of error and each spies the error of others and fails to see his own.» Vid. Hunted heretic..., p. 67).

${ }^{117}$ De Trinitatis erroribus [1 $1^{\mathrm{a}}$ ed., 1531], ed. facsímil, Minerva, 1965.

118 Defensio orthodoxae fidei de sacra Trinitate, contra prodigiosos errores Michaelis Serveti Hispani..., Ginebra, R. Estienne, 1554.

119 Contra libellum Calvini, [1 ${ }^{\mathrm{a}}$ ed., 1612]. Vid. la traducción al francés de Etienne BARILIER, Contre le libelle de Calvin après la mort de Michel Servet, Ginebra, Zoé, 1998. Dicho tratado, escrito en 1554, no llegaría a la imprenta hasta casi sesenta años después, pues el libro fue interceptado por la censura a instancias de Calvino.

120 «For the things contained in it are given obscurely and often in enigmas and inscrutable questions, which have been in dispute more than a thousand years without any agreement, nor can there be agreement without love, which breaks and a appeases all controversies and drives away ignorance. Yet 
que pudiera ser castigado, ya que su único delito había sido «de pensamiento». De ahí el célebre párrafo de Castellio tantas veces citado como uno de los primeros manifiestos a favor de la tolerancia y en pro de la libertad de conciencia: «Matar a un hombre no es defender una doctrina, es matar a un hombre. Cuando los ginebrinos ejecutaron a Servet, no defendieron una doctrina, mataron a un ser humano. No prueba uno su fe quemando a un hombre, sino haciéndose quemar por ella»..$^{121}$

Varios años después, en su libro titulado El arte de dudar y de creer, de ignorar y de saber, ${ }^{122}$ Castellio volvería a insistir en el problema del conocimiento religioso. En su opinión, la fe no tenía nada en común con el conocimiento mundano, tantas veces identificado con la lógica matemática: «Creer es dar crédito a lo que se ha dicho, sea verdadero o falso. A veces, lo falso se cree no menos que lo verdadero. Pero no puede decirse lo mismo del conocimiento. Lo falso no puede ser conocido, aunque pueda ser creído. En resumen, la fe acaba donde empieza el conocimiento».123

Para Castellio, ante tal situación de incertidumbre, lo único que resultaba claro es que no sabemos lo suficiente como para juzgar y perseguir a nadie por sus ideas, y que un «hereje» es simplemente aquél con quien no estamos de acuerdo. ${ }^{124}$ La única actitud consecuente frente a los llamados «errores» y a quienes los defienden debería ser la piedad, unida a la atenta observación y concentración en uno mismo y en la propia interioridad, para que ningún asomo de ira, acrimonia o ambición dificulten la claridad de juicio y la eficacia de la per-

for this cause the earth is filled with innocent blood.» Vid. Roland H. BAINTON, «Sebastian Castellio. Champion of Religious Liberty. 1515-1563», en Roland H. BAINTON, Bruno BECKER, Marius VALKHOFF y Sape VAN DER WOUdE, Castellioniana. Quatre études sur Sébastien Castellion et l'idée de la tolérance, Leiden, Brill, 1951, p. 41.

121 «Tuer un homme ce ne pas protéger une doctrine, mais c'est tuer un homme. Quand les Genevois on tué Servet, ils n'ont pas défendu une doctrine, mais ils on tué un homme. Affirmer sa foi, c'est ne pas brûler un homme, c'est plutôt se faire brûler». Sébastien CASTELLION, Contre le libelle de Calvin..., p. 161. Vid. also la novela de Stefan ZwEIG, Castellio contra Calvino. Conciencia contra violencia, Barcelona, Acantilado, 2001, p. 196.

122 Sebastian CASTELlio, De arte dubitandi et confidendi ignorandi et sciendi [ $1^{\mathrm{a}}$ ed., 1563], ed. de Elisabeth FEIST HIRSCH, en Reale Accademia d'Italia. Studi e documenti,VII, Roma, 1937. Existe una edición más reciente, también de E. Feist, publicada en Leiden, Brill, 1981. Vid. también Elisabeth FEIST HiRsch, «Castellio's De arte dubitandi and the Problem of Religious Liberty», en B. BECKER (ed.), Autour de Michel Servet et de Sébastien Castellion, Haarlem, H. D. Tjeenk Willink \& Zoon N. V., 1953, pp. 244-258.

123 «To believe is to give credence to what is told, whether true or false. Sometimes the false is believed no less than the true. But the same cannot be said of knowing. The false cannot be known though it may be believed. To be brief, where knowledge begins faith ends». Vid. BAInTON, Castellioniana..., p. 57.

124 «In view of all this uncertainty, we must define the heretic simply as one with whom we disagree.»Vid. Bainton, Castellioniana..., p. 64. 
suasión: «En todas las disputas y guerras hay siempre un elemento de ceguera y obstinación derivado del amor a uno mismo».125

Tal era el mensaje que Servet le había dirigido en 1531 al reformador religioso de Basilea, Juan Ecolampadio, durante su estancia en la ciudad, con la esperanza de no verse perseguido, pese a los «errores» que su libro sobre los errores de la Trinidad pudiera contener:

«Si me hallas en error en un solo punto, no debes por eso condenarme en todos, pues según eso no habría mortal que no debiera ser quemado mil veces, ya que sólo conocemos en parte. Los mayores apóstoles erraron una y otra vez. Y aunque sabes que Lutero se equivoca egregiamente en ciertos aspectos, no por eso le condenas en el resto [...]. Tal es la fragilidad humana que condenamos a los demás como impostores e impíos, pero nunca a nosotros mismos: nadie reconoce sus errores». ${ }^{126}$

Más allá de los posibles errores y aciertos que enfrentaron a Calvino y Servet en un duelo doctrinal sin solución, el «error» que Calvino nunca llegó a reconocer, y por el que la historia continuará juzgándolo, fue su falta de misericordia. Profundamente agraviado ante las provocaciones de quien, de la forma más insultante, se atrevió a cuestionar no sólo su persona sino la misma esencia divina, Calvino tomó una decisión equivocada que en el futuro iba a invertir irónicamente los papeles desempeñados por ambos contendientes, convirtiendo el proceso real contra Servet en un imparable proceso moral e historiográfico contra su acusador. ${ }^{127}$ Para el jefe de la iglesia ginebrina, como representante de Dios en la tierra, su deber no era otro que servir de brazo ejecutor de la ira divina. Pero la imagen medieval del Dios majestuoso y colérico que durante muchos siglos se había impuesto a los fieles pronto se convertirá en un recuerdo del pasado.

Buen ejemplo de ello -salvando las, a menudo sutiles, distancias entre historia y ficción-, es la actitud mostrada por un personaje de uno de los libros más representativos de los nuevos ideales humanistas del Renacimiento. En el libro I de la Utopía de Tomás Moro («acerca del estado óptimo de una república»), el cardenal Morton quien, «zarandeado por las vicisitudes de la fortuna,

125 «In all contentions and wars there is always an element of blindness and obstinacy derived from self-love.» Vid. BAINTON, Castellioniana..., p. 77.

126 «Si in tuo spiritu [...] in uno errrantem noveris, non propterea debuisses in caeteris damnare, nam secundum hoc nemo est mortalium, qui non esset millies comburendus: ex parte enim omnes cognoscimus, et maximi Apostolorum fuerunt aliquando in errore, nec Lutherum in caeteris damnas, etiamsi eum errare optime videas [...] Conditionis humanae ea est infirmitas, ut nostris exceptis, caeterorum spiritus iudicemus impostores et impios, nam errata sua nullus intelligit.» (Calv. op., VIII, p. 862).

127 Vid. Marianne CARbonnier-Burkhard, «Les procès de Michel Servet à Vienne et a Gèneve (1553)», en Valentine ZUBER (ed.), op. cit., pp. 27-52.

Hispania Sacra, LXII

125, enero-junio 2010, 181-211, ISSN: 0018-215-X 
había adquirido en medio de tantos y tan graves peligros aquella experiencia de las cosas que cuando se posee no se pierde fácilmente», ${ }^{128}$ estaba sentado a la mesa con un grupo de personas entre los que se contaban un fraile y un falso bufón. Éste no dejaba de provocar al fraile burlonamente:

«-Vosotros [los frailes] sois los mayores vagabundos del mundo.

$\mathrm{Al}$ acabar de decir el bufón estas palabras, todos miraron hacia el cardenal, vieron que nada tenía que objetar y se echaron a reír de buena gana, excepto el fraile que [...] se agravió y enfadó de tal manera que no pudo contener las invectivas, llamándolo bribón, maldiciente, escandaloso e hijo de perdición, y acudiendo a las más terribles imprecaciones de las Sagradas Escrituras [...]. El cardenal amonestó suavemente al fraile para que moderara sus ímpetus.

-Pero monseñor -dijo él-, hablo así sólo por el celo que me domina, según debo. Los mismos santos han conocido este celo [...].

- Vuestra intención es quizá loable -le dijo el cardenal-, pero me parece que sería una actitud no sé si más santa, pero sí más prudente, no ponerse al nivel de un necio y evitar una discusión ridícula con un ridículo».129

La ambigüedad del falso bufón, que no obstante «lo hacía con tanto afán que resultaba más creíble que uno verdadero», ${ }^{130}$ volvía a quebrar una vez más la vieja esperanza en la posibilidad de distinguir la verdad del error. El «camino oblicuo»131 que Moro proponía seguir ante las inevitables disensiones, y que ni Calvino ni Servet supieron encontrar, venía a ser el símbolo de una utopía, quizá realizable algún día.

128 Tomás Moro, Utopía [1ª ed., 1516], Madrid, Espasa Calpe, 2007, p. 52.

129 Tomás Moro, op. cit., pp. 66-67.

${ }^{130}$ Ibidem, p. 65.

131 Ibidem, p. 75. 